\title{
Learning High School Biology in a Social Context
}

\author{
Amitabha Basu',2, Deborah Aglira1, James R. Spotila3 \\ ${ }^{1}$ G. W. Carver High School of Engineering and Science, Philadelphia, PA, USA \\ ${ }^{2}$ Department of Biology, Drexel University, Philadelphia, PA, USA \\ ${ }^{3}$ Department of Biodiversity, Earth and Environmental Science, Philadelphia, PA, USA \\ Email: ab59@drexel.edu
}

How to cite this paper: Basu, A., Aglira, D., \& Spotila, J. R. (2017). Learning High School Biology in a Social Context. Creative Education, 8, 2412-2429.

https://doi.org/10.4236/ce.2017.815165

Received: October 11, 2017

Accepted: December 8, 2017

Published: December 11, 2017

Copyright (C) 2017 by authors and Scientific Research Publishing Inc. This work is licensed under the Creative Commons Attribution International License (CC BY 4.0).

http://creativecommons.org/licenses/by/4.0/

\begin{abstract}
In this research, we developed a process that helped students connect cell and molecular biology concepts with problems in context of their lives. Specifically, we supplemented traditional teaching with problem, project and inquiry based laboratories, without changing the structure of the mandated biology curriculum. We ran the process twice, following the classroom based action research model. Our initial foray exhibited better student-developed projects and a modest improvement of test grades. Second time we compared changes in problem solving skills, attitude toward reading, writing and problem solving and improvement of traditional test grades from the beginning and end of the school year. This process made the biological concepts so interesting that by the end of the year nearly all students significantly $\left(t_{(55)}=-8.95, p \leq 0.05\right)$ improved problem-solving skills and some students went further to develop and solve independent inquiries. They also exhibited improved attitude towards reading, writing and problem solving. However, we didn't observe any causal relationship between improvement of problem solving skills and test grade, since its trend showed little difference between first and second trial.
\end{abstract}

\section{Keywords}

Biology Learning, Cell and Molecular Biology, Standardized Curriculum, Problem, Project and Inquiry Based Laboratories,

Learning and Problem-Solving Skills, Test Grades

\section{Introduction}

This paper describes our investigation on the effect of a teacher designed sup- 
plemental interactive learning process supporting introductory biology courses at a high school in the City of Philadelphia. The primary aim of this research was to examine whether application of interactive hands on learning of the biological facts and concepts in the context of appropriate socioeconomic scenarios can improve inquiry type problem solving skills and content knowledge to make biology interesting and meaningful to all students. The secondary aim was to measure the conventional test performance of the same students.

The authors recognized that our students not only disliked Life-Science literature, but they also lacked the study skills to follow the scientific terms, language, facts, and to analyze and understand the data (inductive and deductive reasoning), and conclusions. They were unable to correlate scientific facts with most facets of their lives. It made the biology a boring, dull and useless subject that they were forced to learn. Most were happy if they could pass and forget it, which we believed resulted in poor test performance by $25 \%$ - $30 \%$ of the students.

So we developed and implemented an idea in two iterations to supplement our traditionally time paced core instructions with strategically placed problems, projects and inquires. We believed this strategy helped the students develop their own deductive (research) questions and investigations, and thereby helped them to apply biology concepts to solve social problems instead of standard laboratories (Figure 1). The process supported traditional teaching processes and tests throughout the school year. The students were required to complete a final project developed individually or in small groups based on the topics taught in the class, in addition to a final exam. The students exhibited substantial improvement in skills and ability to solve biological problems. The combined measure identified each student's progress and necessary interventions without any major curricular modification and cost overruns.

\section{Literature Review}

The emphasis on cellular and molecular sciences in high school biology curricula raised awareness of cutting-edge advances in molecular sciences, technology and medicine. Molecular genetics connected evolution with multiple aspects of our lives and society with irrefutable facts (Nishinakamura \& Takasato, 2017; Wang et al., 2014). However, the cross-disciplinary and multi-dimensional nature of cell-molecular biology is challenging for most high school students (Koba \& Tweed, 2016; Cimer, 2012; Tibell \& Rundgren, 2010; Sahdra \& Thagard, 2003; Stewart, 1982). Learning these topics requires a paradigm shift in conceptual understanding and an ability to connect between something tangible, such as anatomy, morphology, life cycle and food-web of living materials and ordinarily intangible molecular and logical rationalizations derived from disparate scientific fields explaining the same. In addition these fact-based materials required the students to learn a completely new scientific and technical language used exclusively in academic and technical circles (Grant \& Lapp, 2011, 
A. About $83 \%$ - $88 \%$ with (end of year) positive interest in reading, writing and problem solving (Semantic Differential)

B. Their reading, writing and math test grades matched their interest $>80 \%-90 \%$ success (pass) but Biology final exam grade varied between $65 \%-72 \%$ success (pass)

C. Cause cited as disconnect between content materials and learner interest and therefore, boring.

D. Hence the question is can we make it meaningful?

$1^{\text {st }}$ design implementation: So, we designed and implemented supplemental hands on and mind in problem solving projects aligned to PA state science std. along with traditional learning processes

Result I: Student generated end of the year final project was a success (Table 1 with data)

But $1^{\text {st }}$ vs $4^{\text {th }}$ mark grades exhibited only modest improvement (Table 3 )

Inference was that the past students may communicate the context between scientific facts and social phenomena better

$2^{\text {nd }}$ modified design implementation: Allow previous year's students act as mentors in the final project in addition to running supplemental hands on-mind in problem solving projects along with traditional teaching and evaluation + Pretest + Semantic Attitude test

A. Pretest done in the beginning of year showed lack of skill set aligned to PA state science standards (Table 7 )

B. Parallel attitude test (semantic differential) showed lack of interest in (science) reading, writing and problem solving (Table 4 )

C. It meant that we faced uphill battel to make biology interesting to our students

Result II: Student generated final projects were resounding success (Table 5),

compared with BMI/Vital sign project (Table 6),

but the trend of test grade improvement remained constant $\sim 85 \%$ (pass) (Table 3 ).

Conclusion: It is possible to increase interest and application in scientific (biology) reading, writing and

problem solving by aligning the content with social and life's context

But that does not guarantee improvement in traditional test grade

This method may be used to measure precise success rate of this multi-point standard based training and assessments for each student and identify and implement necessary course of action.

Figure 1. Model for implementing hands-on and mind-in projects supplementing traditional high school biology course. The design was implemented twice with necessary modifications as described below.

Grant, Fisher, \& Lapp, 2015). It required the first author to teach high school biology with lectures, presentations, videos and simulations, reading, writing, model building, small group tutoring and, sadly, rote memorization of facts (Lu, Cowie, \& Jones, 2010; Bell, 2001; Wood, 2001; Lock, 1998). Technical complexity and the high cost of hands-on cell and molecular biology experiments, equally complicated digital simulations, and lack of resources hindered extensive use of hands-on experiments supporting classroom instructions. However, even excellent simulations cannot illustrate the richness and experience of hands-on exploration and execution of concepts discussed in class. Moreover, the content was taught in isolation from the social contexts which give it relevance. Thus, the students often didn't make connections between theory (concepts) and real-life situations (Penuel, 2016; Leonard \& Chandler, 2003). In order to reduce the disconnect between biology content and student interest and understanding, we discussed learning objectives, lack of improvement of test scores and the other key aspects for improvements with the students. They expressed a dissatisfaction 
with traditional approach and asked for more interesting, effective and hands-on learning practices in line with the inquiry method suggested by the National Research Council (2000). The state and district mandated biology standards and curricula also advocated hands-on learning (PA SAS, 2010) supplementing learning of content knowledge. However, effective learning advocated by the science standards (NRC, 1996) was found to be quite elusive even with watered down college style laboratories or dry simulations with little or no connection to our students' social lives. These techniques lacked the transformative experience assisting students to apply disparate and ordinarily intangible molecular and logical concepts to the tangible living world.

We combined three independent ideas to enable students to read, comprehend, and express the scientific concepts in written format (Grant \& Diana, 2011), learn biological concepts with "Inquiry learning" due to its close similarity with the "scientific method" (NRC, 2000, 1996; Kaufmann, 1959; Dewey, 1938) and organize them insocial context (Penuel, 2016). The problem with inquiry is acquiring conceptual knowledge from direct observations by using deductive questions (Oguz-Unver \& Arabacioglu, 2014) and appropriate hypothesis (NRC, 2000). However, most biology problems, especially at the high school level often do not have any tangible hypothesis. Therefore the end results cannot be used to prove or disprove the hypothesis. With a little accommodation, biological topics can be learned through identifying and solving socially and scientifically relevant multi-disciplinary but ill-defined problems (PBL) (Savery, 2006). Or they can be learned through an extended hands-on inquiry process structured around complex, authentic questions and carefully designed complex but authentic projects and tasks (PjBL) (Regassa \& Morrison-Shetlar, 2009; Wright \& Boggs, 2002). However, all three methods entail a similar but inherently different learning experience (Oguz-Unver \& Arabacioglu, 2014). So, we used multiple problem, projects and inquiries to support high school biology topics.

Our next challenge was time; we had to be pragmatic and adhere to the state's and district's biology standards (PA SAS, 2010) which emphasized learning of specific contents and their evaluation in precise sequence and pacing (School District of Philadelphia: Scope and Sequence). The students were also required to go through traditional assessments stressing factual recall and solving pen and paper based problems (Lock, 1997). But making students learn science content hands-on and in the context of their lives (Koba \& Tweed, 2016) takes time, tends to be confusing and requires multiple mid-course corrections during the learning process (NRC, 2000, 1996).

The solution was to create a process that may help students develop their own deductive (research) questions and investigation, and thereby help them connect biology concepts to social problems (Figure 1). In this student-centered social constructivist approach (Savery, 2006; NRC, 2000, 1996), biology students in small groups chose and applied appropriate biology concepts to explain common and society-wide bio-medical, agricultural and life-style problems (Koba \& 
Tweed, 2016; Lenz \& Willcox, 2012; Domingos-Grilo, 2011; Reiss, 2005). The results were discussed, analyzed and critiqued in class within and among the groups to support the development of reports and presentations, which typically measured progress towards the goals of PBL (Savery, 2006). Final projects were evaluated by both internal and external examiners as an extended form of assessment to reflect a broad range of learning and cognitive outcomes (Cartier \& Stewart, 2000) and genuine understanding (Gardiner \& Farragher, 1999).

The last piece of the puzzle was evaluation of student performance in traditional tests, since a loss of test grades is sometime a problem in investigative classrooms (Domingos-Grilo et al., 2011). We emphasized the importance of test grades to the students involved in this research. One author provided after school tutoring sessions two-three times a week throughout school year, and left all classroom and district mandated benchmark tests in place without any modification. We analyzed the student performance in fourth versus first quarter class (test and quiz) grades for every school year during this research work.

\section{Research Questions}

In this research, we answered the following questions:

- How does the practice of supplemental hands-on projects strengthen students' problem-solving skills and interest in connecting scientific concepts to social problems?

- How does our process affect student performance in traditional tests? Are the skills translational between hands-on projects and traditional tests?

\section{Methods}

In practice, we adopted a student centric and constructivist process as opposed to traditional fact and concept centered approach to cater to all individuals in the biology class, including the teacher. In order to develop an appropriate method, we implemented our strategy twice on two different groups of $9^{\text {th }}$ grade biology students at the Carver High School of Engineering and Science (HSES) in Philadelphia. First, we implemented our strategy with a group of 33 students for a year and analyzed the outcome. We then tweaked the process following the suggestion from our students and colleagues. The modified strategies were reimplemented with two different groups with a total of 55 students (overview in Figure 1).

Settings for designing and implementation of supplemental projects: The first author taught biology at HSES which is a magnet school with a selective admission of students from the whole city. The standards and learning goals for the course were consistent with national and the State of Pennsylvania science standards (NRC, 1996, 2000; PA SAS, 2010). The biology curriculum was developed by the School District of Philadelphia (SDP). The curriculum 
requires teachers to teach the biology basics following a pacing guide (SDP Scope and Sequence) with clearly designated concepts, chapters and resources aligned to the State of Pennsylvania Standards Aligned System (PA-SAS). Both PA-SAS and SDP allowed the curricular units to be supported with hands-on laboratories at the discretion of the teacher and the availability of resources. We made small modifications in the syllabus to integrate the projects seamlessly (Supplement A).

The first author lectured on the topic from assigned texts with intermittent dialogue and discussion with the students (didactic), and promoted memorization and rote learning as productive learning approaches (Lock, 1998). The lectures were scientifically correct and seamlessly followed traditional biology teaching practices and the students' learning was evaluated with traditional content assessments and SDP benchmark tests common to all biology students in the school.

Design of supplemental hands-on problem-solving projects. The students worked on the projects in two stages. The first stage consisted of small demonstrations or hands-on laboratory experiments in which the students learned to align the results with corresponding biology content learned in the class, some of which were inspired by Serendip@ studio projects

(http://serendip.brynmawr.edu/biology/). But the problem identification, solving and interpretation were categorically facilitated by the teacher. These formative projects were done more than once during the school year following the outcome of a syllabus unit. The formative projects were followed by short discussions on the design and selection of final summative projects (DeHaan, 2009). The students completed the summative projects toward the end of the school year. They worked as independent operators with little guidance or direct intervention from the teacher, who acted as a resource and facility manager in these projects (Krajick, 2015).

With few exceptions, most of the students perceived science as a miracle that could be performed only by well-trained scientists, engineers or doctors. For most of these students scientific concepts were beyond their social realms and something that they were forced to learn against their primary beliefs. Based on social constructivist approach, we strongly encouraged the students to develop their scientific and technical thinking in context with relevant social problems (Lenz \& Wllcox, 2012) rather than simple knowledge transmission (Saverym \& Thomas, 1995). This process, in turn, helped them to take more responsibility for their own learning. We encouraged both student-teacher and student-student interactions as ways for students to explore and evaluate ideas, resolve scientific misunderstanding and identify differences (Prawat, 1989), as opposed to transmitting information without contributions from students (Yang, 2002). The students were strongly encouraged to discuss their problems with other faculties and family members. The students learned to do research, real-life simulations, metacognition, data analyses and logical expression (synthesis) through both group discussion, and written and verbal means (Grant, 
Fisher, \& Lapp, 2015).

The formative projects were socially relevant problems aligned to specific parts of the curriculum. The students learned scientific method by measuring and analyzing Body Metabolic Index (BMI); cell structure and function by writing stories and poems, and Mendelian genetics and probability by playing cards. Cell division and sexual reproduction and pedigree analyses were taught with live Zebrafish (Danio rario) spawning, and molecular biology was taught by constructing cDNA and mRNA of human insulin gene with $K^{\prime}$ nex kits and demonstration of green fluorescent protein (GFP) gene cloning in $E$. coli bacteria (Supplement A).

The first year's final challenge was to identify and solve multiple social problems with relevant biological concepts. We looked at the resultant data and added the senior students to mentor the freshmen with the idea that the seniors would inspire and guide younger students to solve problems efficiently. In the second year the final challenge problem was designed to increase awareness of organ and tissue and blood donation, since organ donation in Philadelphia lags surrounding counties. Learning and understanding the complex technicalities of organ donation easily supported cell biology, genetics, molecular biology and evolution. It also supported anatomy sections of the curriculum and facilitated the development of final independent projects. From the social point, organ donation was a worthy cause for the students to understand because organ donations give second chances to the recipients and organ donors are real heroes. We emphasized that the organ donation organizations are not organ harvesters and that the donation process is actually designed to reduce any procedural risk, contrary to the common belief (unpublished data).

Evaluation of student performance: The success of our strategy and its applicability in teaching high school biology was identified by successful completion of final student crafted projects and analysis and interpretation of results, and students' performance in friendly competitions. The students were made aware that they need to take and pass all tests including district mandated benchmarks, and we recorded the first versus fourth quarter grade averages.

Outcomes of all projects were evaluated by multiple measures independent of the test grades. In-class projects were evaluated by the peers, mentors, student teachers and authors. This practice led to the development of final projects either by pairs or individual students. The final project reports and presentations were evaluated by a combination of internal and external evaluators. We discussed the rough copies of the results and analyses in class to aid the development of final reports and presentations. They were then evaluated by external examiners following pre-determined rubrics to measure the progress of students' understanding of the problem (Supplement C). We developed the evaluation rubrics following Intel International Science and Engineering Fair (ISEF) evaluation rules (IRPSR, 2017), and relevant PA-SAS (Table 7) and NRC inquiry (NRC, 2000) standards (Table 7). In our rubric, we put the most emphasis on students' understanding of the scientific and 
technical problems of the project, and development of solution based on pertinent biological concepts (Supplement C).

We also applied a few specially designed assessments, which were pre- and midterm (and external SDP benchmark II) tests developed in house with items aligned to the above-mentioned standards to measure the relevancy of our process (Table 7). Pre- and midterm tests contained both multiple choice and short answer items and the benchmark contained all but one multiple choice item.

Semantic differential test of student attitude: Students' interest in science subjects was estimated with a semantic differential analysis with seven paired adjectives (like the Likart scale) applied to three different questions about their attitudes toward reading, writing, and problem solving (Osgood, Suci, \& Tannenbaum, 1957) (Supplement B).

\section{Results}

First year: Evaluation of final summative projects grades showed that among 33 students, $26(78.8 \%)$ received $80 \%$ (B) or above, $5(15.2 \%)$ received below $80 \%$ (B) and $2(6.06 \%)$ were unsuccessful (Table 1). The percent of these students with positive attitudes (using semantic pair of adjectives) towards reading, writing and problem solving were 85.7, 88.6 and 68.6, respectively (Table 2). Average class grades composed mostly of traditional test and quizzes in the $1^{\text {st }}$ and $4^{\text {th }}$ marking periods changed from 76.2 to 82 (Table 3 ).

Second year: In this iteration, we compared of the project, test and attitude grades from introduction and completion of the trial. Evaluation of the project

Table 1. $1^{\text {st }}$ Final project presentation grade. The data showed number and percent of students either received $80 \%$ or above and below grades. The $80 \%$ grade cut-off was used to keep parity with average traditional final test grade in Table 3 .

\begin{tabular}{ccc}
\hline No. of Students & $\begin{array}{c}80 \% \text { or above } \\
\text { (Std. deviation of grade) }\end{array}$ & $\begin{array}{c}\text { Below } 80 \% \\
\text { (Std. deviation of grade) }\end{array}$ \\
\hline 33 (one section) & $26 \%$ or $78.8 \%(3.02)$ & $7 \%$ or $21 \%(13.4)$ \\
\hline
\end{tabular}

Table 2. $1^{\text {st }}$ Attitude Test was done in parallel with final project (33 students 2005). The data showed percent of students with positive attitude towards either reading, writing or problem solving in biology. The students were made aware more than once that the test was about their attitude towards science.

\begin{tabular}{|c|c|c|c|}
\hline \multicolumn{4}{|c|}{$\begin{array}{l}\text { Seven pairs of semantics (adjectives) with three positive trends } \\
\text { (range value max. } 3 \rightarrow 1 \mathrm{~min} .=(+21 \text { to }+7) / 7 \text { ), three negative trends } \\
\text { (range value max. }-3 \rightarrow-1=(-21 \text { to }-7) / 7) \text { and one neutral trend (range value }=0 / 7 \text { ) } \\
\text { for problem solving, reading and writing in science were used, } \\
\text { where all pairs weighted equal. We identified any value }<1 \text { as either neutral } \\
\text { or negative attitude of a student towards that specific attribute. }\end{array}$} \\
\hline No. of Students & Reading (\%) & Writing (\%) & Problem Solving (\%) \\
\hline 33 & 85.7 & 88.6 & 68.6 \\
\hline
\end{tabular}


Table 3. Student performance in the traditional $1^{\text {st }}$ Mark (pre) and $4^{\text {th }}$ Mark (post) life-science content assessments following the implementation of the model stated in the Figure 1. The sample size for this assessment was small and the standard deviation values showed large variations in the assessment data.

\begin{tabular}{cccc}
\hline $\begin{array}{c}\text { School } \\
\text { (year of study) }\end{array}$ & $\begin{array}{c}\text { Average } \\
1^{\text {st }} \text { Mark Grade } \\
(\text { Std. deviation })\end{array}$ & $\begin{array}{c}\text { Average } \\
4^{\text {th }} \text { Mark Grade } \\
(\text { Std. deviation })\end{array}$ & $\begin{array}{c}\text { No. of } \\
\text { students }\end{array}$ \\
\hline HSES $\left(1^{\text {st }}\right)$ & $76.2(11.3)$ & $82(9.7)$ & 33 \\
HSES $\left(2^{\text {nd }}\right)$ & $73.8(21.5)$ & $87.8(11.3)$ & 55 \\
\hline
\end{tabular}

grades showed that 12 out of 63 students (19\%)in the introductory(BMI) project and $47(71.2 \%)$ out of 55 students in the final project received $80 \%$ or above (Table 5). The 26 students out of 63 (41.3\%) were unsuccessful in the introductory project but none in the final project. A match paired t-test of introductory and final project grades from the same55 students gave $t_{(55)}=-8.95, p \leq 0.05$ with a Pearson correlation of 0.26 (Table 6).

The grades from the specially made tests with items aligned to PA-SAS and NRC inquiry standards relevant to ISEF rules, showed that 6.06 and 45.5 percent students solved problems in pretest and midterm test (posttest), respectively and $50 \%$ students exhibited success in content knowledge in both (Table 7). In the SDP benchmark 2 test taken after three weeks of midterm examination $25.4 \%$ students solved problems, $93.1 \%$ showed content knowledge and $75.4 \%$ showed predictive skills (63.6\% in pretest) (not shown).

This year the $1^{\text {st }}$ and $4^{\text {th }}$ marking periods average class grades mainly from tests were 73.8 and 87.8 , respectively (Table 3 ), and the percent of students with positive attitude towards reading, writing and problem solving were 16.7 and 83.2, 15.2 and 88.6, and 15.2 and 70.5, respectively (Table 4).

Development of independent scientific inquiries: Multiple students independently and in groups of three students continued their investigations one year after and presented their results at the (Regional) G. W. Carver Science Fair at the Temple University, Philadelphia, Delaware Valley Science Fair (DVSF), AIDS conference at the Children's Hospital of Philadelphia and National Math, Science and Engineering Achievement Competition (MESA). Some of the winning projects aligned to biology were listed in Table 8.

\section{Discussion and Conclusion}

This study was meant to evaluate the effectiveness of small hands-on inquiry style projects supplementing traditional high school biology coursework. The results showed that it successfully improved problem solving skills (Table 5 and Table 6) without compromising test grades (Table 3), which was a major concern in this setting (Domingos-Grilo et al., 2011). More students improved their problems solving skills while retaining content knowledge as evidenced by preand midterm test data (Table 7). We compared the student success in the in house (Table 7) and standardized benchmark 2 results stated in the previous 
Table 4. Beginning and year end (pre- and post-) attitude Tests were done in parallel with $1^{\text {st }}$ vital-sign (basic metabolic index or BMI) and final biology projects, respectively (66 and 55 students in two sections 2010). The data showed percent of students with positive attitude towards either reading, writing or problem solving in biology. The students were made aware more than once that the test was about their attitude towards science.

\begin{tabular}{|c|c|c|c|}
\hline \multicolumn{4}{|c|}{$\begin{array}{l}\text { Seven pairs of semantics (adjectives) with three positive trends } \\
\text { (range value max. } 3 \rightarrow 1 \mathrm{~min} .=(+21 \text { to }+7) / 7) \text {, three negative trends } \\
\text { (range value max. }-3 \rightarrow-1 \mathrm{~min} .=(-21 \text { to }-7) / 7) \text { and one neutral trend } \\
\text { (range value }=0 / 7) \text { for problem solving, reading and writing in science } \\
\text { were used, where all pairs weighted equal. We identified any value }<1 \text { as either } \\
\text { neutral or negative attitude of a student towards that specific attribute. }\end{array}$} \\
\hline $\begin{array}{l}\text { Total no. of Students } \\
\text { (Two sections) }\end{array}$ & Reading (\%) & Writing (\%) & Problem Solving (\%) \\
\hline 63 (beginning of yr.) & 16.7 & 15.2 & 15.2 \\
\hline 55 (end of yr.) & 83.2 & 88.6 & 70.5 \\
\hline
\end{tabular}

Table 5. Number and percent of students received $80 \%$ or above in $1^{\text {st }}$ vital-sign (basic metabolic index or BMI) and final biology projects. The $80 \%$ grade cut-off was used to keep parity with average traditional final test grade in Table 3.

\begin{tabular}{ccccc}
\hline Total no. of Students & Introductory & BMI project & Final project & \\
\hline Grade (Percent) & $\geq 80$ & $<65$ & $\geq 80$ & $<65$ \\
63 (beginning of yr.) & $27(42.9 \%)$ & $26(41.3)$ & & \\
55 (end of yr.) & & & $47(71.2 \%)$ & 0 \\
\hline
\end{tabular}

Table 6. Matched pair $t$-test (two sample for means) of $1^{\text {st }}$ BMI vs final project grades of 55 students showing significant ( 95\% percentile) improved performance (Interpretation needs a Statistician).

\begin{tabular}{ccc}
\hline & BMI & Final \\
\hline Mean & 14.30455 & 25.82061 \\
Variance & 93.40669 & 21.47187 \\
Observations & 55 & 55 \\
Pearson Correlation & 0.266521 & \\
Hypothesized Mean Difference & 0 & \\
$d f$ & 54 & \\
$t$ Stat & -8.95258 & \\
$\mathrm{P}(\mathrm{T} \leq t)$ one-tail & $1.48 \mathrm{E}-12$ & \\
$t$ Critical one-tail & 1.673565 & \\
\hline
\end{tabular}

section, which showed better evidence of improved student performance in all three groups of standards. The students showed slim improvement in predictive skills from pre- to benchmark tests (63.3\% to $75.4 \%)$. Ultimately, for several students the experience was so transformative that they successfully completed independent science fair projects (Table 8). 
Table 7. PA standards relevant to ISEF project evaluation rules were used in SDP Benchmark tests and grade interpretation of the following in house tests. These tests differed from the traditional $1^{\text {st }}$ versus $4^{\text {th }}$ marking period in class tests and their grades were never reflected in actual class grades in any form. The measured success was percent of students answered $\geq 50 \%$ test items correctly. The pretest result was compared with that of midterm test as posttest. The standards were separated in three groups for the ease of explaining the data.

Problem solving skills:

A.2.1.1: Experimental design, hypothesis, management \& interpretation of data.

A.2.1.3: Use data to draw inference \& conclusion.

A.3.3.1: Describe or interpret recurring patterns that form the basis of biological classification, chemical periodicity, geological order, or astronomical order.

Predictive skills:

A.3.1.2: Analyze and predict the effect of making a change in one part of a system on the system as a whole.

A.3.2.1: Compare the accuracy of predictions represented in a model to actual observations and behavior.

Content knowledge:

B.1.1.1: Explain how structure determines function at multiple levels of organization (e.g., chemical, cellular, anatomical).

B.1.1.2: Compare and contrast the structural and functional similarities and differences among living things (e.g., classify organisms into classification groups, compare systems).

B.1.1.3: Compare and contrast cellular processes

(e.g., photosynthesis and respiration, meiosis and mitosis, protein synthesis and DNA replication).

$\begin{array}{cccc} & \text { Problem solving skills } & \text { Predictive skills } & \text { Content knowledge } \\ & \text { A.2.1.1 } & & \text { B.1.1.1 } \\ & \text { A.2.1.3 } & \text { A.3.1.2 } & \text { B.1.1.2 } \\ \text { PA Standards } & \text { A.3.3.1 } & \text { A.3.2.1 } & \text { B.1.1.3 } \\ \text { Pretest } & 6.06 & 63.64 & 48.48 \\ \text { Midterm test } & 45.45 & & 50\end{array}$

Table 8. Sparks of real scientific investigations and discoveries.

1) Few places in the Delaware river around Philadelphia may contain mercury higher than the level allowed by Environmental Protection Agency's standard.

2) Deadly Gamma irradiation at NASA's International space station (ISS) can break dormancy of basil seeds. (Ocimumbasilicum Cinnamon) The project interpreted the data collected at the ISS between 2007-2009.

3) Crickets are cleverer than Cockroaches.

4) Design a cheap mechanical prosthetic arm.

5) All races in Philadelphia can donate and receive organs from each other.

6) We are responsible of AIDS of our babies: please teach the young mothers.

The improvement of students' attitudes towards reading, writing and solving problems (Table 4) was in line with improvement in content knowledge, since increasingly complex traditional tests did not depress the average class grade (Table 3). But their confidence level in problems solving differed with actual skills either in projects or standard aligned tests (Table 4 and Table 7). All project grades came from both verbal and written interpretation of the results, but the students scored better in the multiple-choice tests $(93.1 \%$ in Benchmark 
2 versus $50 \%$ in midterm). Our data didn't show relationship between improvement in problem-solving skills and performance in traditional tests, since some students remained unsuccessful irrespective of their performance in the final project. Following midterm and Benchmark 2 no more standard aligned tests were added with final project and traditional tests, since the students grew wary of all tests.

It appears, the concomitant use of common learning skills such as reading, writing, recalling the scientific facts, identifying connections between a problem (test question) and its answer from the knowledgebase, developing a solution by combining disparate information (from knowledgebase) helped most students succeed both in projects and tests. Our evaluation process measured multiple parameters of biology learning akin to $21^{\text {st }}$ century skills (21st Century Skills Assessment, 2007).

In the future, we shall investigate the relationship between the skill to interpret and express project data with proper scientific concepts and the ability to answer problem solving questions in traditional tests.

\section{Acknowledgements}

Authors gratefully acknowledge support received from the Gift of Life Foundation and Donor are Heroes, L. Drew Betz Chair Professorship, and Department of Biology, Drexel University and Nutter Center for Community Partnership, University of Pennsylvania, and Wister Institute, Philadelphia. The AIDS project was supported by grant from Center for Disease Control, USA through the School District of Philadelphia. We had to request necessary supplies and instruments from Drexel University Biology and Chemistry departments and Science in Motion (http://phillysim.org/staff.html part of the State of Pennsylvania Science in Motion), respectively. The University of Pennsylvania outreach donated the zebrafish, and allowed students to use laboratory facilities.

\section{References}

$21^{\text {st }}$ Century Skills Assessment: A Partnership for 21st Century Skills e-paper (2007) http://www.p21.org/storage/documents/21st_Century_Skills_Assessment_e-paper.pdf

Bell, E. (2001). The Future of Education in Molecular Life Sciences. Nature Reviews: Molecular Cell Biology, 2, 221-225. https://doi.org/10.1038/35056610

Cartier, J. L., \& Stewart, J. (2000). Teaching the Nature of Inquiry: Further Developments in a High School Genetics Curriculum. Science and Education, 9, 247-267. https://doi.org/10.1023/A:1008779126718

Cimer, A. (2012). What Makes Biology Learning Difficult and Effective: Students' Views. Educational Research and Reviews, 7, 61-71.

DeHaan, R. L. (2009). Teaching Creativity and Inventive Problem Solving in Science. CBE-Life Sciences Education, 8, 172-181. https://doi.org/10.1187/cbe.08-12-0081

Dewey, J. (1938). Experience and Education. Kappa Delta Pi, USA.

Domingos-Grilo, P., Reis-Grilo, C., Ruiz, C., \& Mellado, V. (2011). An Action-Research Programme with Secondary Education Teachers on Teaching and Learning Photosynthesis. Journal of Biological Education, 36, 72-80. 
Gardiner, P. G., \& Farragher, P. (1999). The Quantity and Quality of Biology Laboratory Work in British Columbia High Schools. School Science and Mathematics, 99, 197-204. https://doi.org/10.1111/j.1949-8594.1999.tb17474.x

Grant, M., \& Lapp, D. (2011) Teaching Science Literacy, Educational Leadership, 68. http://www.ascd.org/publications/educational-leadership/mar11/vol68/num06/Teachin g-Science-Literacy.aspx

Grant, M., Fisher, D., \& Lapp, D. (2015) Reading and Writing in Science. Corwin, A SAGE Co. Thousand Oaks, California, USA.

International Rules for Pre-College Science Research, IRPSR International Science and Engineering Fair (2017) https://student.societyforscience.org/international-rules-pre-college-science-research

Kaufmann, F. (1959) John Dewey's Theory of Inquiry. The Journal of Philosophy, 56, 826-836. https://doi.org/10.2307/2022592

Koba, S., \& Tweed, A. (2016) Hard to Teach Biology Concepts: A Framework to Deepen Student Understanding. National Science Teachers Association Press, Arlington, Virginia, USA.

Krajick, J. (2015). Project-Based Science. Science Teacher, 82, 25-27.

Lenz, L., \& Willcox, M. K. (2012). Issue-Oriented Science: Using Socioscientific Issues to Engage Biology Students. The American Biology Teacher, 74, 551-556. https://doi.org/10.1525/abt.2012.74.8.4

Leonard, W. H., \& Chandler, P. M. (2003). Where Is the Inquiry in Biology Textbooks? The American Biology Teacher, 65, 485-487. https://doi.org/10.2307/4451546

Lock, R. (1997). Is There Life in Science 2000? Journal of Biological Education, 31, 83-85. https://doi.org/10.1080/00219266.1997.9655537

Lock, R. (1998). Advanced-Level Biology-Is There A Problem? The School Science Review, 80, 25-29.

Lu, T., Cowie, B, \& Jones, A. (2010). Senior High School Student Biology Learning in Interactive Teaching. Research in Science Education, 40, 267-289.

https://doi.org/10.1007/s11165-008-9107-8

Nishinakamura, R., \& Takasato, M. (2017) Human Development, Heredity and Evolution. Development, 144, 2099-2103. https://doi.org/10.1242/dev.150565

NRC (National Research Council) (1996). National Science Education Standards. Washington, DC: The National Academies Press.

NRC (National Research Council) (2000). Inquiry and the National Science Standards. Washington DC: The National Academy Press.

Oguz-Unver, A., \& Arabacioglu, S. (2014). A Comparison of Inquiry-Based Learning (IBL), Problem-Based Learning (PBL) and Project-Based Learning (PJBL) in Science Education. Academia Journal Educational Research, 2, 120-128.

Osgood, C. E., Suci, G., \& Tannenbaum, P. (1957). The Measurement of Meaning. Urbana IL: University of Illinois Press.

PA SAS (2010) Academic Standards for Science and Technology and Engineering Education (Secondary). Pennsylvania Department of Education. http://www.pdesas.org/Standard/Views

Penuel, W. R. (2016). Studying Science and Engineering Learning in Practice. Cultural Studies of Science Education, 11, 89-104. https://doi.org/10.1007/s11422-014-9632-x

Prawat, R. S. (1989). Teaching for Understanding: Three Key Attributes. Teaching and Teacher Education, 5, 315-328. https://doi.org/10.1016/0742-051X(89)90029-2 
Regassa, L. B., \& Morrison-Shetlar, A. (2009). Student Learning in a Project-Based Molecular Biology Course. Journal of College Science Teaching, 38, 58-67.

Reiss, M. J. (2005). SNAB: A New Advanced Level Biology Course. Journal of Biological Education, 39, 56-59. https://doi.org/10.1080/00219266.2005.9655961

Sahdra, B., \& Thagard, P. (2003). Procedural Knowledge in Molecular Biology. Philosophical Psychology, 16, 477-498. https://doi.org/10.1080/0951508032000121788

Savery, J. R. (2006). Overview of Problem-based Learning: Definitions and Distinctions. Interdisciplinary Journal of Problem-Based Learning, 1, 9-20.

Savery, J. R., \& Thomas, M. D. (1995). Problem Based Learning: An Instructional Model and Its Constructivist Framework. Educational Technology, 35, 31-38.

Stewart, J. H. (1982). Difficulties Experienced by High School Students When Learning Basic Mendelian Genetics. The American Biology Teacher, 44, 80-82 + 84 + 89.

Tibell, L. A. E., \& Rundgren, C.-J. (2010). Educational Challenges of Molecular Life Science: Characteristics and Implications for Education and Research. CBE-Life Science Education, 9, 25-33. https://doi.org/10.1187/cbe.08-09-0055

Wang, G. D., Xie, H. B., Peng, M. S., Irwin, D., \& Zhang, Y. P. (2014). Domestication Genomics: Evidence from Animals. Annual Review of Animal Bioscience, 2, 65-84. https://doi.org/10.1146/annurev-animal-022513-114129

Wood, E. J. (2001). Molecular Biology and Biochemistry Teaching over Past 50 Years. Nature Reviews: Molecular Cell Biology, 2, 217-221. https://doi.org/10.1038/35056600

Wright, R., \& Boggs, J. (2002). Learning Cell Biology as a Team: A Project-Based Approach to Upper-Division Cell Biology. Cell Biology Education, 1, 145-153. https://doi.org/10.1187/cbe.02-03-0006

Yang, L. L. (2002). Brief History of Eastern and Western Science Education Development. Taipei: Wen-Chin. 


\section{Supplement A}

\section{1) Eighteen-week plan (Semester I) \\ Date: September-2009; Department: Science \\ Course: BIO-I; Grade(s)/Level(s): $9^{\text {th }}-$ Grade}

\begin{tabular}{|c|c|}
\hline Week 1 (Sep 8-11) & Week 10 (Nov 9-13) \\
\hline Introduction to Courses & Test $02(1)$ \\
\hline UNIT I: Scientific Method \& Inquiry & Student design Inquiry Lab (2) Introduction to \\
\hline Scientific Method: notes, journals and Lab. book (4) & UNIT V: Cellular Respiration Gift of Life (GoL) \\
\hline Intro to projects and research (Lab) (1) BMI project Intro & the breakdown of food (1) Project \\
\hline Week 2 (Sep 14-18) & Week 11 (Nov 16-20) (Benchmark 1) \\
\hline Prediction/ Inferring \& Scientific Lingo (1) \& (Lab) (1) & The breakdown of food (lab) (1) Issue (GoL) Project \\
\hline UNIT II: Introduction to Chemistry & The structure \& function of ATP (2)outline \\
\hline Review of Chemistry (1) Develop BMI report & The steps of Aerobic Cellular Respiration (2) \\
\hline Week 3 (Sep 21-25) & Week 12 (Nov 23-25) \\
\hline Rev. of Chemistry (3) Complete BMI report & Anaerobic Cellular Respiration (2) Intro to content \\
\hline Chemistry of Water (1) & UNIT VI: Photosynthesis Research (GoL) \\
\hline Properties of Water and $\mathrm{pH}(\mathrm{Lab})(1)$ & Introduction to Photosynthesis (1) or Resp. Lab (1) \\
\hline Week 4 (Sep 29-Oct 2) (Test Rev. Oct 2) & Week 13 (Nov 30-Dec 4) \\
\hline Chemistry of Water (1) & Introduction to Photosynthesis (1) Intro to online \\
\hline Organic Chemistry (2) & Photosynthetic Pigments (1) Research (GoL) \\
\hline Macromolecule (Lab) (1) & Steps of Photosynthesis (2) \\
\hline Test Review (1) & Pigments lab (1) \\
\hline Week 5 (Oct 05-09) (Test 1-Oct 8) & Week 14 (Dec 07-11) (Test Rev: Dec 10-11) \\
\hline Test $01(1)$ & UNIT VI: Molecular Basis of Inheritance \\
\hline UNIT III: Cell Structure and Function & Nucleotides \& DNA replication (2) GoL online res. \\
\hline Cell Theory (2) (Biogenesis and spontaneous generation) & Transcription from DNA to RNA (1) or model Lab (1) \\
\hline Techniques of using Microscope (1) \& Lab (1) & Test Review (1) \\
\hline Week 6 (Oct 13-16) & Week 15 (Dec 14-18) (Test 3-Dec 16) \\
\hline \multirow{3}{*}{$\begin{array}{l}\text { Cell Size (2) } \\
\text { Molecular Transport Lab (Osmosis) (1) }\end{array}$} & Test 03 (1) Res. Info to \\
\hline & Transcription from DNA to RNA (1) rough draft (GoL) \\
\hline & Translation from mRNA to Proteins (1) \& model Lab (1) \\
\hline Week 7 (Oct 19-23) & Week 16 (Dec 21-23) (Holiday Dec 24-Jan 03) \\
\hline Molecular Transport (2)Intro to cell story project & DNA technology (3) GoL topic selection \\
\hline Cell Organelle (2) \& Lab (1) & Discussion on Molc. Basis of inheritance (1) \\
\hline Week 8 (Oct 26-30) & Week 17 (Jan 04-08) \\
\hline \multirow{5}{*}{$\begin{array}{l}\text { Types of Cells (2) Cell Story project } \\
\text { Correlation between cells and organisms (1) } \\
\text { UNIT IV: Enzymes } \\
\text { Overview of Enzyme Action (2) }\end{array}$} & UNIT VIII: Mitosis \& Meiosis GoL outline due \\
\hline & Understanding cell division (Worksheet) (1) \\
\hline & Understanding Mitosis I (1) \& II (1) (Worksheets) \\
\hline & Understanding Meiosis (1) (Worksheet) \\
\hline & Introduction to Cell cycle (1) \\
\hline Week 9 (Nov 02-06) (Test Rev: Nov 5-6) & Week 18 (Jan 11-15) (Test Rev. Jan 14-15) \\
\hline Enzyme Lab (1) Complete cell stories & Mutations in DNA (2) Project outline \& rough draft \\
\hline Substrate \& Receptor mimics (2) & Mitosis \& Meiosis Lab (1) corrected \& returned \\
\hline Regulation of Enzyme (1) & Test Review (1) (For Test 04 on Jan 24) \\
\hline Test Review (1) & Mid-year end of $1^{\text {st }}$ Semester Exam \\
\hline
\end{tabular}




\section{2) Eighteen-Week Plan (Semester II)}

Date: January 2010; Department: Science

Course: BIO-I; Grade(s)/Level(s): $9^{\text {th }}$-Grade

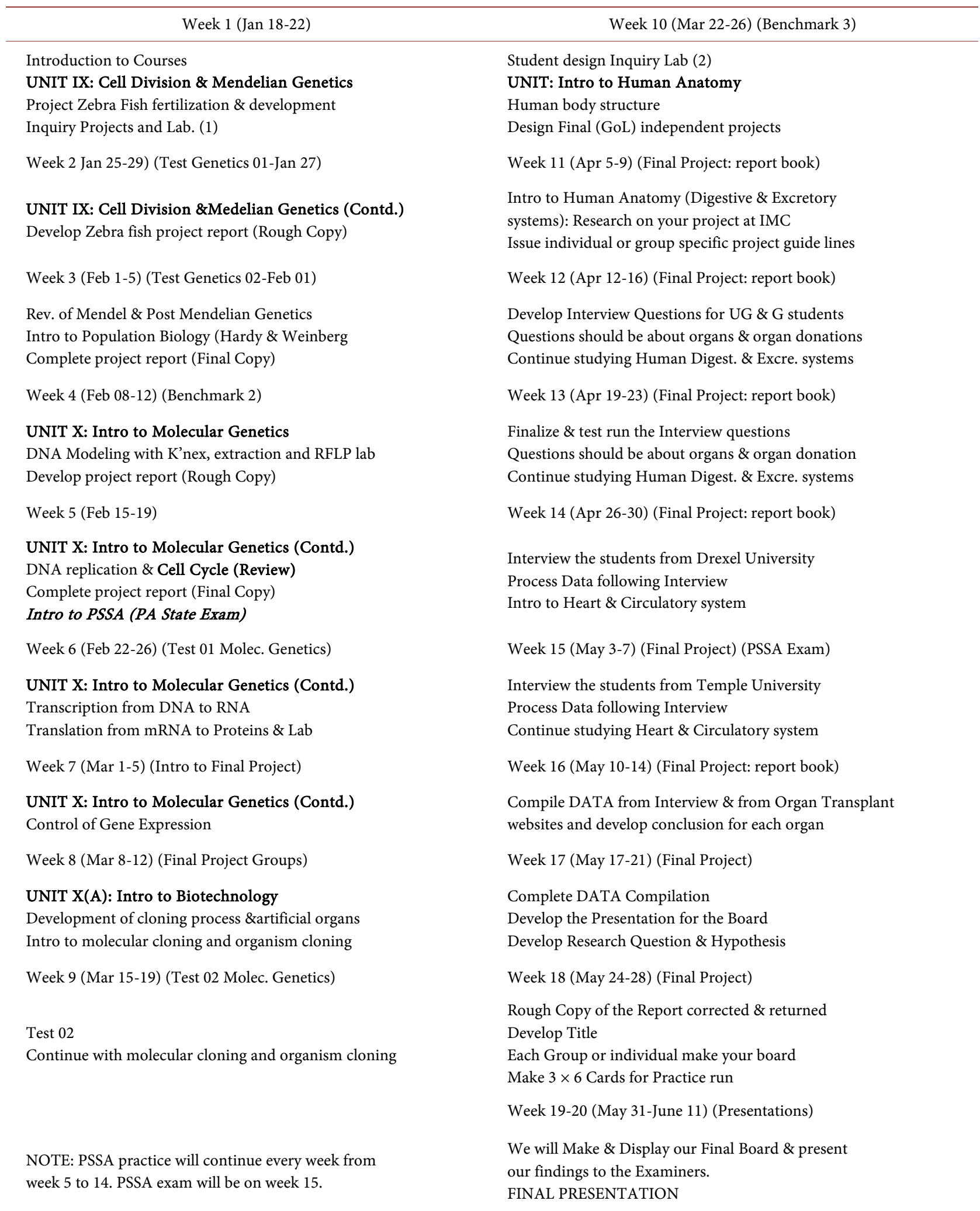




\section{Supplement B}

Attitude Tests [Note: Each test containing the statement and adjectives were printed on a separate sheet of paper]

Attitude Test (Semantic Differential) Date:

o The list of adjectives measure how you feel toward the IDEA listed at the top of the page

o Place ONE X on the space that shows how closely the objectives reflect how you feel toward the subject heading above the adjectives

O Place only ONE $\mathbf{X}$ for each pair of adjectives

IDEA: I AS A READER

\begin{tabular}{ccccccccc}
\hline & $\begin{array}{c}\text { very } \\
\text { closely } \\
\text { related }\end{array}$ & $\begin{array}{c}\text { quite } \\
\text { closely } \\
\text { related }\end{array}$ & $\begin{array}{c}\text { only } \\
\text { closely } \\
\text { related }\end{array}$ & neutral & $\begin{array}{c}\text { only } \\
\text { closely } \\
\text { related }\end{array}$ & $\begin{array}{c}\text { quite } \\
\text { closely } \\
\text { related }\end{array}$ & $\begin{array}{c}\text { very } \\
\text { closely } \\
\text { related }\end{array}$ & \\
\hline $\begin{array}{c}\text { Strong } \\
\text { Nice }\end{array}$ & - & - & - & - & - & - & - & Weak \\
Fast & - & - & - & - & - & - & - & Awful \\
Distasteful & - & - & - & - & - & - & - & Thasteful \\
Successful & - & - & - & - & - & - & - & Unsuccessful \\
Active & - & - & - & - & - & - & - & Passive \\
Pleasant & - & - & - & - & - & - & - & Unpleasant \\
\hline
\end{tabular}

IDEA: I AS A WRITER

\begin{tabular}{|c|c|c|c|c|c|c|c|c|}
\hline & $\begin{array}{c}\text { very } \\
\text { closely } \\
\text { related }\end{array}$ & $\begin{array}{l}\text { quite } \\
\text { closely } \\
\text { related }\end{array}$ & $\begin{array}{c}\text { only } \\
\text { closely } \\
\text { related }\end{array}$ & neutral & $\begin{array}{c}\text { only } \\
\text { closely } \\
\text { related }\end{array}$ & $\begin{array}{l}\text { quite } \\
\text { closely } \\
\text { related }\end{array}$ & $\begin{array}{c}\text { very } \\
\text { closely } \\
\text { related }\end{array}$ & \\
\hline Strong & - & - & - & - & - & - & - & Weak \\
\hline Nice & - & - & - & - & - & - & - & Awful \\
\hline Fast & - & - & - & - & - & - & - & Slow \\
\hline Tense & - & - & - & - & - & - & - & Relaxed \\
\hline Successful & - & - & - & - & - & - & - & Unsuccessfu \\
\hline Active & - & - & - & - & - & - & - & Passive \\
\hline Pleasant & - & - & - & - & - & - & - & Unpleasant \\
\hline
\end{tabular}

IDEA: I AS A PROBLEM SOLVER

\begin{tabular}{|c|c|c|c|c|c|c|c|c|}
\hline & $\begin{array}{c}\text { very } \\
\text { closely } \\
\text { related }\end{array}$ & $\begin{array}{l}\text { quite } \\
\text { closely } \\
\text { related }\end{array}$ & $\begin{array}{l}\text { only } \\
\text { closely } \\
\text { related }\end{array}$ & neutral & $\begin{array}{l}\text { only } \\
\text { closely } \\
\text { related }\end{array}$ & $\begin{array}{l}\text { quite } \\
\text { closely } \\
\text { related }\end{array}$ & $\begin{array}{c}\text { very } \\
\text { closely } \\
\text { related }\end{array}$ & \\
\hline Dishonest & - & - & - & - & - & - & - & Honest \\
\hline Dull & - & - & - & - & - & - & - & Sharp \\
\hline Fast & - & - & - & - & - & - & - & Slow \\
\hline Tense & - & - & - & - & - & - & - & Relaxed \\
\hline Successful & - & - & - & - & - & - & - & Unsuccessful \\
\hline Active & - & - & - & - & - & - & - & Passive \\
\hline Strong & - & - & - & - & - & - & - & Weak \\
\hline
\end{tabular}




\section{Supplement C}

The rubric for in school science presentations was adopted from Intel International Science and Engineering Fair (ISEF) and G. W. Carver Science Fair (Temple University), Philadelphia. The Rubric is divided into two parts, which are as follows:

\begin{tabular}{|c|c|}
\hline Strengths of the Project & $\begin{array}{l}\text { Suggested Improvements } \\
\text { and Modifications }\end{array}$ \\
\hline Appropriate use of scientific principle & $\begin{array}{l}\text { Requires additional research on } \\
\text { scientific principle }\end{array}$ \\
\hline Technical details are appropriate & Requires additional technical details \\
\hline Appropriate use of scientific method & Follow scientific method \\
\hline Topic is original and scientifically interesting & $\begin{array}{c}\text { Requires additional } \\
\text { research on topic selection }\end{array}$ \\
\hline Problem statement/hypothesis appropriate & Clarify problem statement/hypothesis \\
\hline Appropriate sample size/no. of trials & $\begin{array}{l}\text { Use appropriate sample size/no. } \\
\text { of trials/controls }\end{array}$ \\
\hline Appropriate data analyses & Requires appropriate data analyses \\
\hline Data/Graphs/Tables presented clearly & Use appropriate data/graphs/tables \\
\hline Appropriate use of Math/Statistical procedures & Use appropriate Math/Statistical procedures \\
\hline Conclusions followed data analyses & $\begin{array}{l}\text { Inadequate data analyses/support } \\
\text { for conclusion }\end{array}$ \\
\hline Appropriate log book/notes supplied & $\begin{array}{l}\text { Requires appropriate data } \\
\text { logging process/notes }\end{array}$ \\
\hline Appropriate procedures followed & Rethink procedures \\
\hline Appropriate citation of Scientific Literature & Update/expand Bibliography \\
\hline Appropriate use of resources & Requires additional support/resources \\
\hline Appropriate layout of display board & $\begin{array}{c}\text { Improved layout/preparation } \\
\text { of display board }\end{array}$ \\
\hline (For Engineering Projects only) & (For Engineering Projects only) \\
\hline Workable solution of research statement & Unacceptable solution of research statement \\
\hline (For Team projects only) & (For Team projects only) \\
\hline $\begin{array}{l}\text { Contributions of EACH } \\
\text { team member evident }\end{array}$ & $\begin{array}{c}\text { Contributions from } \\
\text { each team member unclear }\end{array}$ \\
\hline
\end{tabular}

